\title{
EUROPEAN UNION TERMINOLOGY UNIFICATION - DIRECTIONS FOR THE CONTRASTIVE STUDY OF TWO SLAVIC AND TWO NON-SLAVIC LANGUAGES (BUlgarian, POLISH, MODERN GREEK AND ENGLISH)
}

\section{ILIANA GENEW-PUHALEWA}

ilianag@interia.pl

University of Silesia, Katowice, Poland

\begin{abstract}
This study attempts to characterize terminology unification in the European Union legislation, regarding both content and form. It analyzes terms related to the thematic field of environmental law in four official EU languages: two Slavic (Bulgarian and Polish) and two non-Slavic (Modern Greek and English). Different types of relations between the languages under comparison suggest possible directions for further comparative study. The comparison aims to identify differences and similarities in the componential structure, formal-grammatical structure, word formation structure, form variantivity, origin and formal status. The study may also testify to the presence of linguistic convergence processes in the multilingual European Union.
\end{abstract}

Key words: term, European Union terminology, terminology unification, Bulgarian, Modern Greek, Polish, comparative study

\section{Introduction}

This study will attempt to expose a tendency of unification of the terminology used in the legal documents of the European Union (EU). The study concerns the terms related to a certain subject field in four official EU languages: two Slavic, Bulgarian and Polish, and two non-Slavic, Modern Greek (Greek) and English. Environmental Protection Legislation has been chosen as a thematic example, for the reason that it is an area which reflects the state of contemporary professional knowledge in the natural and formal sciences as well in the social sciences. The excerption covers legislative texts of the EU, published on the official internet portal of the EU (www.europa.eu), and units included in the e-glossaries of the EU (IATE, EuroVoc, ETDS).

The basis for a hypothesis to be put forward, that the terminology used in the EU legislative texts becomes uniform in different languages, is on the one hand the result of an initial observation and on the other hand a well-known extralinguistic fact: EU legislation is harmonized. That means that the fundamental differences among the legal systems of the EU member states have been eliminated. It can therefore be assumed that the identical content of the legislative texts (the unification of the content) involves 
unification of the language form. The more so because experts have been consciously seeking to abolish the differences in the terminology:

Different legal terminology forms an obstacle to European integration. (Heutger 2003:3)

The desired unification of the EU legislation terminology lexicon in different languages is difficult to reconcile with another current requirement in relation to the law, including legislative language: to be understood, optimally simplified and accessible to both professionals and ordinary citizens:

However, there is nevertheless a new European legal culture emerging that requires law that can be understood not only by legal experts but also even by laymen without any legal skills. (Heutger 2003:5)

The question arises whether the best way to eliminate the inconvenient diversity of specialized vocabulary in legal practice is the use of internationalisms, as recommended in general in the formal and natural sciences, or whether to establish a common legal language (Ristikivi 2002, Seymour 2005). A contrastive study allows one to capture the current trends in term creation and EU terminology work, understood as "activities aimed at improving the particular terminology glossaries" (Lukszyn, Zmarzer 2001: 86).

The study, due to the selected object, is situated in the context of contrastivetypological linguistic studies, more precisely in the terminological lexicology. Taking into account the triad "form - function -meaning" (Jarcewa 1985:12, Koczerhan 2009:72) the equivalence of the meaning and function of the terminological units is stated. This is because the terms used in EU legislation in the various languages are defined in the same way. The legal systems of the EU member states have been harmonized, thus the analysis does not take into account the issue of the conceptual structure and focuses on the formal characteristics of the language (cf formal structure in Popova 1985:30 and formal parameter in Lukszyn \& Zmarzer 2001:109-110). Note that the issue of the conceptual content of the terms and their definitions belongs to the science from which they originate. However, the possession of the legal definition (formulated in a EU legal act) by the terminological unit will serve as a strict criterion to distinguish terms from non-terms, since there is no substantive difference between one and the other (regarding "quasi-terms" and "pseudo-terms" see Zmarzer 1991:123, Lukszyn, Zmarzer 2001: 24,25, 40, 41)

Different types of relations between the languages under comparison suggest possible directions for further comparative study. The languages arrange in a few opposite pairs depending on the adopted classification criterion. From the perspective of their genetic relations these are (1) two Slavic languages, Bulgarian and Polish (abbreviated as bg and pl) and two non-Slavic, Modern Greek and English (gr and en). From the perspective of their typological relations these are (2) two Balkan languages (i.e. classified to the Balkan Linguistic League), Bulgarian and Greek, and two nonBalkan languages, Polish and English. This scheme will be maintained as well if we take into account the graphical systems used in the languages we compare: (3) two using Latin, Polish and English, and two using other alphabets, Bulgarian and Greek (the graphic form could be of importance for the adaptation of the term, cf the term in situ below). From the viewpoint of the morphological type these are (4) inflecting languages (synthetic), Polish and Modern Greek, which can be contrasted with non-inflecting languages (analytical), Bulgarian and English. 
Apart from strict linguistic criteria, other criteria can be applied to sort the chosen languages, acknowledging extralinguistic facts which affect the processes of terminogenesis. These are:

a) the period of the countries' membership in the EU: two EU languages with longer experience in the EU, both non-Slavic, and two with shorter experience, both Slavic;

b) the burden of the communist past (possible russification of the legal terminology of People's Republics and influence of "newspeak"): two post-communist, Bulgarian and Polish (both Slavic) and two unburdened with a communist past, English and Greek (both non-Slavic).

c) Eventually in asymmetrical opposition Bulgarian, Polish and Modern Greek as "post-slavery" contrast with English (unburdened with foreign dominance) according to the criterion of experience of foreign dependence. Building national institutions, including those of justice of their own independent states in the first half of the XXth century after a long period of dependence (foreign slavery) is a historical fact common to the Bulgarians, Greeks and Poles. Related to this fact is the sometimes purist approach to problems of term creation, which has implications extant even today (Yanakiev 1977 83-96. Mazur 1961:16-17, Stoberski 1982:9-10, Filopoulos 1994). These observations form a wider framework for comparative studies on terminology.

A concept which requires more substantial comment at the beginning of this paper is unification, because it is understood in different ways. Some experts call the unification of the terminology a certain method or procedure (an element of intended work), aimed at bringing order to the use of national terminology in a given terminological lexicon. For example, according to Lukszyn \& Zmarzer the unification (in addition to normalization, standardization, codification, regulation and others) is "a kind of terminology work", i.e. "activity aimed at improving the terminological lexicons". Popova understands unification similarly (1990:13).

Elsewhere in the same publication Lukszyn and Zmarzer define unification as follows:

Generally speaking, the procedure of unification of Lt (terminological lexicon) is reduced to a subordination of a set of conventional language signs to the national language standards. (2001: 86)

The unification, as a method which brings order to the terminological systems, is seen by Vinogradov and Platonova as part of harmonization i.e. a method of insuring accordance of the national terminology with the international one.

\footnotetext{
Методы унификации терминов используются и в случае межьязыкового упорядочения, т.е. обеспечения сопоставимости терминологии национального и международного уровней, или гармонизации.
}

(Winogradow \& Platonowa 1999: IV, § 27)

The internalization of terminological phenomena is the other common way of understanding unification. For example the name of the organization which encourages the process of internalization and the overcoming of language barriers in special 
terminology pl Międzynarodowa Organizacja Unifikacji Neologizmów Terminologicznych (International Organization for Unification of Terminology Neologisms), indicates that unification is associated with internalization. Similarly D. Kierzkowska in her monograph on the problems of legal translation uses the term unification ambiguously, in some cases in terms of internationalization of the terminological units after the harmonization of the legal system with the international one (Kierzkowska 2008:159-164). The author writes about some "new elements" entering into the Polish legal language, which come from international systems "as a result of the trend towards unification of national legislation with the international system of European Community Law" (2008:160). Kierzkowska has a critical attitude towards this phenomenon: she sees in the unreasonable use of internationalisms, rather than native terms and phrases connected with traditions of Polish legal language, an "overpowering European influence" and "snobbery" (e.g. raport instead of sprawozdanie, rezolucja instead of uchwała, procedura instead of tryb postepowania, rekomendacja instead of zalecenie etc.) (2008: 167-168).

In this paper, under the concept unification of the EU terminology, the author understands the intentional or unintentional (e.g. as a result of the interpreter's/ translator's work) uniformity of the terminological units in different language versions of EU legislation, both on the content level and the formal level.

The above cited authors Lukszyn and Zmarzer postulate briefly in their monograph as follows:

St (terminology system) is Lt (terminology lexicon) structured under the F-, K- and Rparameters" (2001:109),

where F-parameter is the formal parameter, K-parameter is the conceptual parameter and $\mathrm{R}$-parameter is the relational parameter. F-parameter takes into account formal language characteristics such as: componential structure, formal-grammatical structure, word formation structure, form variantivity, origins, formal status, etc. The contrastive analysis of the terminology in the selected subject field is based here in the cited research proposal of Lukszyn and Zmarzer.

\section{Results of the contrastive analysis}

In terms of componential structure the terminological units can be divided into one-, two- or multi-word. In the analyzed set of terms the multi-word units definitely dominate (mostly two-word). This situation constitutes the norm, because in terminological theory and practice there is a conviction that word-combinations better reflect the content of the concept, as they have both the formal exponents for both the generic characteristics and the distinctive features of the concepts which they signify (Hałas 1995:73, 83; Valeontis, Zeriti, Nikolaki, 1999:10, 15-16, Popova 1985). Cf the one-word-term for generic concept:

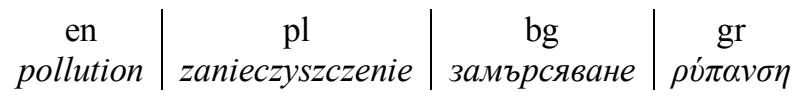


with two-word-terms:

\begin{tabular}{|c|c|c|c|}
\hline $\begin{array}{l}\text { en } \\
\text { domestic pollution } \\
\text { toxic pollution } \\
\text { physical pollution } \\
\text { chemical pollution }\end{array}$ & $\begin{array}{l}\mathrm{pl} \\
\text { zanieczyszczenia krajowe } \\
\text { zanieczyzczenia toksyczne } \\
\text { zanieczyszczenie fizyczne } \\
\text { zanieczyszczenie chemiczne }\end{array}$ & $\begin{array}{l}\text { bg } \\
\text { битово замърсяване } \\
\text { токсично замърсяване } \\
\text { физическо замърсяване } \\
\text { химическо замърсяване }\end{array}$ & 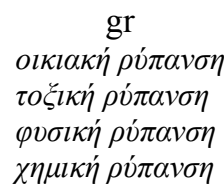 \\
\hline
\end{tabular}

In cases where the terms under comparison are not equivalents from the point of view of their formal structure, because in one of the languages a one-word-term is used and in the others multi-componential terms are used, it often happens the one-word-term is a compound word or derivative, components of which have a similar or identical meaning to the lexical meaning of the term elements in the multi-word terminological units. $\mathrm{Cf}$ the Polish term zanieczyszczenie lotne 'gaseous pollution' (en olfactory pollution) with

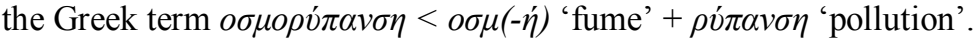

Although similarities among componential structure of the EU terms are more common than their differences, it is worth noting the lack of equivalence in the case of the key term environment, which is a one-word-term in almost all the EU languages, except for in Bulgarian, which uses the multi-componential term околна среда, a calque of the Russian term окружаюшая среда. The Bulgarian term was created before the political changes in 1989, during the People's Republic. Cf:

$$
\begin{array}{l|c|c}
\text { en } & \mathrm{pl} & \mathrm{gr} \\
\text { environment } & \text { środowisko } & \pi \varepsilon \rho \iota \beta \dot{\alpha} \lambda \lambda \lambda_{o v}
\end{array}
$$

The grammatical structure of the terminological units is compared on the basis of their belonging to the given lexicogrammatical category. There is a categorical monotony in this case: the term-words are usually nouns, and the elements of multicomponental terms are mostly nouns, or adjectives, or (rarely) participles. The comparative analysis of multi-word terms draws attention to the lexicogrammatical classification of both the main element and the dependent element(s).

The main element as a rule is a noun, but the subordinate element can be a noun in a non-nominative-case combined without a preposition (in Polish and Greek), or an attributive noun (in English), or a noun joined with a preposition (in Bulgarian), or an adjective (in all four languages), or a participle (in all four languages). The examples below illustrate the most common patterns:

a) Adjective (subordinate defining element) + noun (main defined element) ${ }^{1}$ en ecotoxicological properties; pl właściwości ekotoksykologiczne; bg

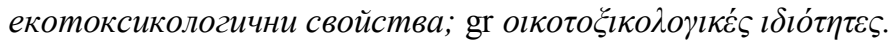

In the listed units the elements-adjectives are compound words which have an identical word-formation-structure, composed of classical roots eko-, tox(-ic), log- and a corresponding adjectival suffix - al (en), -iczn- (pl), -ичн- (bg), - $\iota к-$ (gr).

\footnotetext{
${ }^{1}$ In Polish with inverted word order - adjective in postposition.
} 
b) Participle (subordinate defining element) + noun (main defined element) en protected area; pl obszar chroniony; bg защитена територия; gr

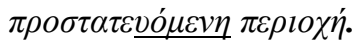

c) Noun + noun

en risk assessment; pl ocena ryzyka; bg оценка на риска; gr вкті́нбб

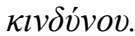

The subordinated (defining) nouns in the above formations combine with the main noun without a preposition in Polish and Modern Greek, which are inflecting languages (the defining nouns are in the Genitive case). The attributive noun in the English term also combines without a preposition, whereas in Bulgarian it combines with a preposition. In other languages, in place of the English formation [attributive noun + noun], which probably served as a pattern for the term creation, an adjective may appear. Cf:

\author{
en water infiltration into the ground \\ pl inflitracja wody do ziemi

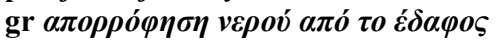 \\ en plant protecton product \\ pl środek ochrony roślin
}

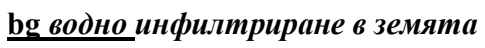

bg продукт за растителна зашита

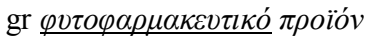

As for the model to follow, the language of its source is in doubt, because the different language versions of the legislative texts have equal status and equal legal force, so none of the languages is considered as a source, nor are the others considered as a target in the translation (regarding hidden translation see Kierzkowska 2008:147).

In some cases a foreign (English) formal model of the term is followed too literally, see en the warning of danger and bg предупреждаваш знак за опасност, where warning (a Present Participle form) in Bulgarian corresponds to an Active Present Participle предупреждаващ + noun знак, instead of the common participial adjective предупредителен (e.g . предупредителен знак - 'warning sign (road)'). This avoids the undesirable phenomenon of transterminological homonymy. The Polish and Greek

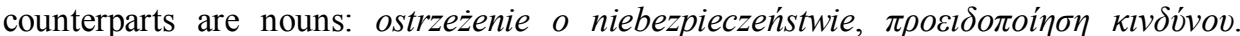
Overall, from the formal-grammatical perspective, as well as from the componential, similarities are many and substantial.

The term is a linguistic unit with the structure of a word or a word combination and those words can be analyzed from the point of view of word formation . This is another characteristic included in the F-parameter. In the comparison of genetically unrelated languages the word formation analysis is limited, which is why the observations here only take into account the type of word formations. The observations show that the vast majority of the analyzed one-word-terms and term-elements are derivatives or compound words. The second ones (the compound words) more often come from the LSP's of the formal and natural sciences, while they are created from Greek or Latin roots, hence the material identity of the forms is not rare, despite a lack of genetic relationship among the languages, cf: 


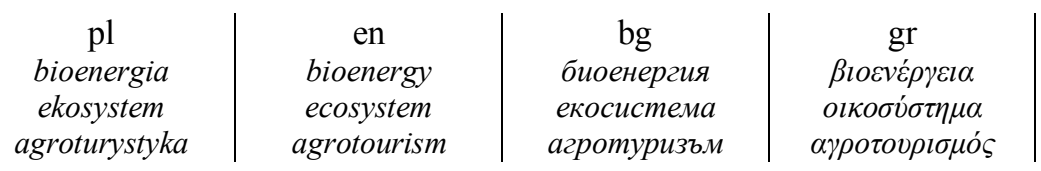

However, as regards the formative derivatives, their form depends on the derivative resources of the national terminological systems. Affixation seems to be the dominant type of derivation for both the Slavic (bg and pl) and non-Slavic (en and gr) terms. The observations on the word-formation structure of the adjectives, which are subordinated elements of two-word terms [adjective + noun], with an international base (so one can expect a formal equivalence among the terms), show that the Bulgarian derivational resource of affixes for term-creation is richer than the English and Greek ones. This may indicate not only the potential of the Slavic affixation, but also the instability of the Bulgarian terminological system, as well as a lack of standardization. Cf:

\begin{tabular}{|c|c|c|c|}
\hline $\begin{array}{l}\quad \text { en } \\
\text { physiographic factors } \\
\text { geological factors } \\
\text { biological factors } \\
\text { climatic factors } \\
\text { evolutionary process }\end{array}$ & \begin{tabular}{l}
\multicolumn{1}{c}{$\mathrm{pl}$} \\
czynniki fizjograficzne \\
czynniki geologiczne \\
czynniki biologiczne \\
czynniki klimatyczne \\
proces ewolucyiny
\end{tabular} & \begin{tabular}{l}
\multicolumn{1}{c}{ bg } \\
физиографски фактори \\
геоложски фактори \\
биологичн фактори \\
климатични фактори \\
еволючионен прочес
\end{tabular} & 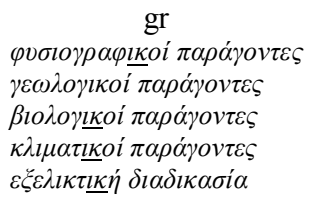 \\
\hline
\end{tabular}

In the comparison of the languages the fertility of Greek term creation comes into prominence: Modern Greek presents a unique derivational potential, cultivated by the purist-oriented term creators. An illustration of this assertion may be the Greek counterparts of the term-elements in situ 'in the original, natural place' and ex situ 'beyond the original, natural place', borrowed in the other languages from Latin. They fulfill an attributive function in the two-word terms. In both the Slavic terminology systems these elements remain barbarisms, i.e. unadapted elements (in Bulgarian even graphically), whereas Greek uses elements of native origin: єлıтó

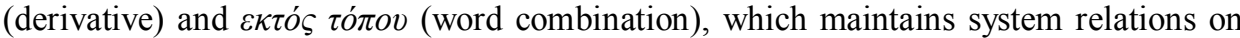

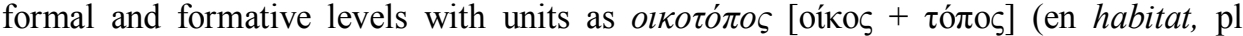
siedlisko, bg местообитание). In addition, the adverb влıто́лоv is a member of the derivational nest, cf the adjective $\varepsilon \pi \imath \tau o ́ \pi \imath o \varsigma,-\alpha,-O$ 'local'.

\begin{tabular}{|c|c|c|c|}
\hline $\begin{array}{l}\text { en in situ sources } \\
\text { pl źródła in-situ } \\
\text { bg източници in-situ }\end{array}$ & gr $\varepsilon \pi \imath \tau o ́ \pi о \nu ~ \pi \eta \gamma \varepsilon ́ \varsigma$ & $\begin{array}{l}\text { ex situ sources } \\
\text { źródta ex-situ } \\
\text { източници ex-situ }\end{array}$ & 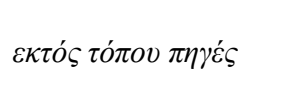 \\
\hline $\begin{array}{l}\text { en in situ conservation } \\
\text { pl ochrona in-situ } \\
\text { bg in-situ опазване }\end{array}$ & 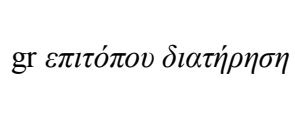 & $\begin{array}{l}\text { ex situ conservation } \\
\text { ochrona ex-situ } \\
\text { ex-situ опазване }\end{array}$ & 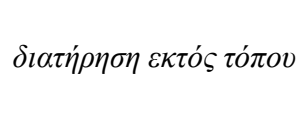 \\
\hline
\end{tabular}

The variantivity of the terminological units, defined here as a parallel usage of short forms and full forms, is another characteristic within the formal parameter of the terminological lexicon. The comparison of the set of terms in the four languages from 
borrowings from English often become internationalisms, especially if they contain classical elements (see Dictionary of English Anglicisms 2001, Stoberski 1982).

The assertions as to the origin of the terms we study are based on the comparison of an arbitrarily selected group of terminological units (total 25). These are multi-word terms, with the same main (determinate) element, which means a generic feature 'action'. It is the element of Greek origin < $\alpha v \alpha \dot{\lambda} \lambda v \sigma l \varsigma$, respectively: gr $\alpha v \alpha \dot{\lambda} \nu \sigma \sigma \eta$, en analysis, pl analiza, bg анализ. The multi-componential units are evidently semantic calques of one original formation, therefore the differences will occur in the subordinated elements, which can be of native origin or borrowings. Thus in 9 cases of a total of 25 we are dealing with internationalisms of Greek origin. E.g.

\begin{tabular}{|c|c|c|c|}
\hline $\begin{array}{l}\text { en } \\
\text { ecosystem analysis } \\
\text { microbiological } \\
\text { analysis } \\
\text { physicochemical } \\
\text { analysis } \\
\text { chromatographic } \\
\text { analysis }\end{array}$ & $\begin{array}{l}\quad \mathrm{pl} \\
\text { analiza ekosystemu } \\
\text { analiza } \\
\text { mikrobiologiczna } \\
\text { analiza fizyko- } \\
\text { chemiczna } \\
\text { analiza } \\
\text { chromatograficzna }\end{array}$ & \begin{tabular}{l}
\multicolumn{1}{c}{ bg } \\
екосистемен анализ \\
микробиологичен \\
анализ \\
физикохимичен \\
анализ \\
хроматографски \\
анализ
\end{tabular} & 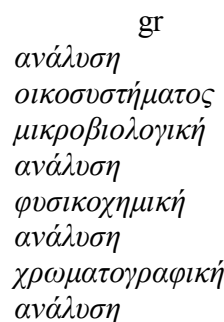 \\
\hline
\end{tabular}

In 5 of 25 cases the Polish, Bulgarian and English units are of identical origin: their elements are internationalisms from Latin, or anglicisms. The Greek terms differ, cf:

\begin{tabular}{|c|c|c|c|}
\hline $\begin{array}{l}\quad \text { en } \\
\text { risk analysis } \\
\text { process analysis } \\
\text { social analysis }\end{array}$ & $\begin{array}{l}\quad \mathrm{pl} \\
\text { analiza ryzyka } \\
\text { analiza procesowa } \\
\text { analiza } \\
\text { sociologiczna }\end{array}$ & $\begin{array}{l}\text { bg } \\
\text { анализ на риска } \\
\text { прочесен анализ } \\
\text { социален анализ }\end{array}$ & 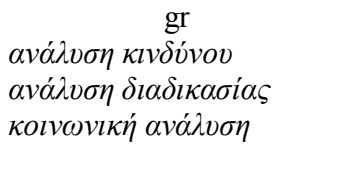 \\
\hline $\begin{array}{l}\text { cost- } \\
\text { effectiveness } \\
\text { analysis }\end{array}$ & $\begin{array}{l}\text { analiza } \\
\text { efektywności } \\
\text { naktadów }\end{array}$ & $\begin{array}{l}\text { анализ на разходи и } \\
\text { икономически ефект }\end{array}$ & $\begin{array}{l}\alpha v \alpha ́ \lambda v \sigma \eta \quad \kappa o ́ \sigma \tau o v \varsigma- \\
\alpha \pi o \tau \varepsilon \lambda \varepsilon \sigma \mu \alpha \tau \iota \kappa o ́ \tau \eta \tau \alpha \varsigma\end{array}$ \\
\hline
\end{tabular}

In four cases (4/25) we note a similarity between Bulgarian and Polish units as a result of the genetic relations of these languages, e.g.

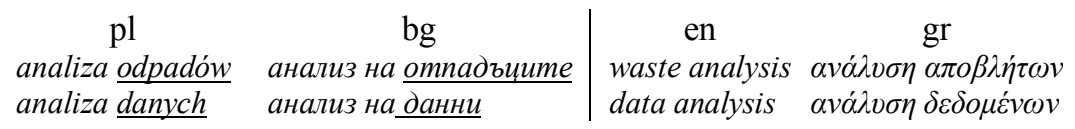

In two cases (2/25) Greek, Polish and English units are partly similar, but the Bulgarian ones differ. The similarity is a result of the use of the element cost, borrowed also in Greek through Italian (<coston) but absent in Bulgarian, e.g:

\begin{tabular}{|c|c|c|c|}
\hline $\begin{array}{l}\mathrm{pl} \\
\text { analiza kosztówi } \\
\text { zvsków }\end{array}$ & $\begin{array}{l}\text { en } \\
\text { cost-benefit } \\
\text { analysis }\end{array}$ & 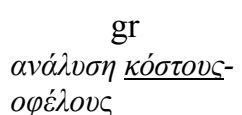 & $\begin{array}{l}\mathrm{bg} \\
\text { анализ на съотномението } \\
\text { разход-полза }\end{array}$ \\
\hline
\end{tabular}


In one case a term of the same origin occurs in Greek, Bulgarian and in English, but of another origin in Polish, cf:

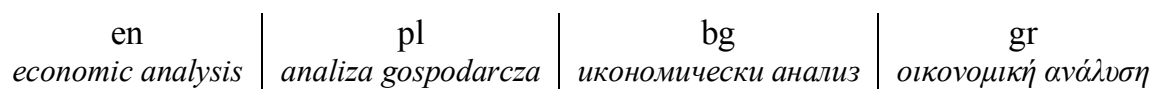

Subordinated term elements of different origins can be noted in 7 of 25 cases, in which the terminological lexicons of the languages use native lexical elements, e.g:

\begin{tabular}{|c|c|c|c|}
\hline $\begin{array}{l}\quad \quad \text { en } \\
\text { sensitivity } \\
\text { analysis } \\
\text { pollutant } \\
\text { analysis } \\
\text { noise analysis } \\
\text { water analysis }\end{array}$ & $\begin{array}{l}\quad \mathrm{pl} \\
\text { analiza wrażliwości } \\
\text { analiza } \\
\text { zanieczyszczeń } \\
\text { analiza hałasu } \\
\text { analiza wód }\end{array}$ & 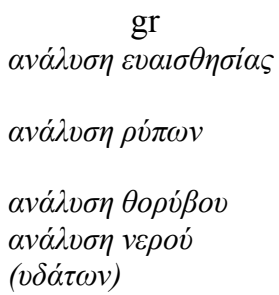 & $\begin{array}{l}\text { анализ на } \quad \text { gg } \\
\text { чувствителността } \\
\text { анализ на замърсители } \\
\text { шумов анализ } \\
\text { воден анализ }\end{array}$ \\
\hline
\end{tabular}

The interpretation of the simple, otherwise, statistical data, according to which 7 of the 25 Polish, 8 of 25 Bulgarian, 11 of the 25 English and 16 of the 25 Greek terminological units from a selected group show no similarity with the other under comparison in terms of the origin of the subordinated element, enables one to draw the conclusion that the majority of all borrowings occur in the Bulgarian and in the Polish terminologies (languages with shorter experience in the EU, post-communist, Slavic), and the least appear in the Greek. The unique "purity" of the Greek terminology is due not only to consistently purist language policy, but also to the evident fact that the resources of this language supply the international scientific terminology with so-called etymons (Filopoulos 1994, 1998: 2-3, ). It should be emphasized that English being a sourcelanguage for borrowings in other languageswidely uses classical etymons. These assertions, taken from a small sample of the material are not absolute, but do show a tendency.

\section{Conclusion}

The widely understood formal similarity of the terminological units in different languages in great measure determines the understanding of the discourse in a multilingual European context.

Bulgarian, Modern Greek, Polish and English LSP's, which are versions of languages genetically and typologically different, become similar. Similarities among the studied terminological lexicons do not derive from their common origin or typological closeness, but from following a common pattern.

From the synchronous point of view, what is common for English, Bulgarian, Greek and Polish, is their status as official EU languages. For the moment that extralinguistic fact has no evident effect on the condition and the development of the national languages. However, there is a direct reflection in the LSP's. Their unification can be regarded as an indication of contemporary processes of linguistic convergence. 


\section{References}

ETDS - Environmental Terminology and Discovery Service - http:/glossary.bg.eea.europa.eu/ EuroVoc. www.eurovoc.europa.eu

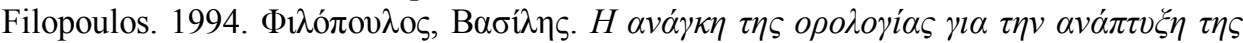

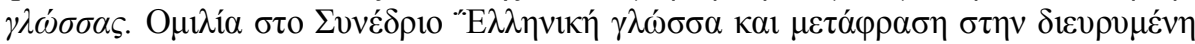

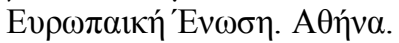

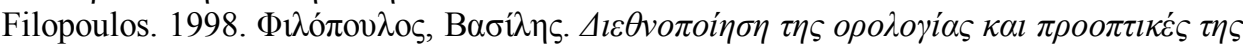

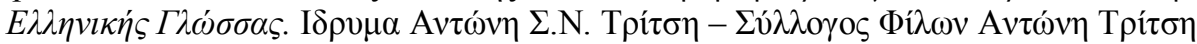

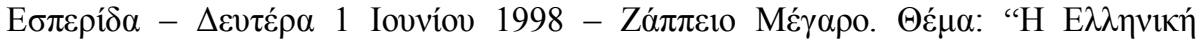

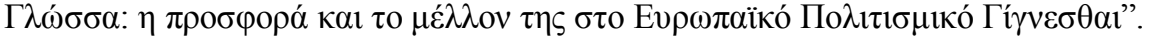

Görlach, Manfred. 2001. Dictionary of the English Anglicisms. Oxford University Press.

Hałas, Bożena. 1995. Terminologia języka prawnego. Zielona Góra.

Heutger, Viola. 2003. "Law and Language in the European Union". In Global Jurist Topics. Volume 3, Issue 1.

IATE - Interactive Terminology for Europe - www.iate.europa.eu

Jarcewa, Ярцева Виктория Н. 1985. „К определению понятия „языковой тип”. Лингвистическая типология, Москва.

Koczerhan, Michajło P. 2009. Podstawy językoznawstwa konfrontatywnego. Wyd. Nowik. Kępa.

Lukszyn, Jurij \& Zmarzer, Wanda. 2001. Teoretyczne podstawy terminologii. Wydział Lingwistyki Stosowanej i Filologii Wschodniosłowiańskiej Uniwersytetu Warszawskiego, Warszawa.

Mazur, Marian. 1961. Terminologia techniczna. Wydawnictwo Naukowo-techniczne. Warszawa. Popova. Попова, Мария. Термини-словосъчетания (из областта на товароподемните и подемно-транспортните машини). БАН. София, 1985.

Ророva. Попова, Мария. 1990. Типология на терминологичнта номиниация. БАН. София.

Ristikivi, Merike. "Latin: The common legal language of Europe?" http://www.juridicainternational.eu/public/pdf/ji_2005_1_199.pdf

Seymour, Edward. 2002. “A common EU legal language?". In Perspectives: Studies in Translatology, 1747-6623, Volume 10, Issue 1, Pages 7 - 13

Stoberski, Zygmunt. 1982. Międzynarodowa terminologia naukowa. Problemy. Postulaty. Oczekiwania. PWN. Warszawa.

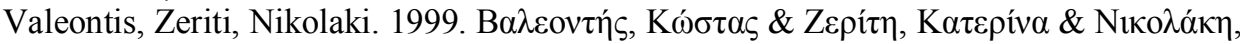

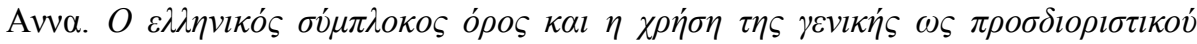

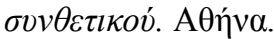

Yanakiev. Янакиев, Мирослав. 1977. Стилистиката и езиковото обучение. София.

Zmarzer, Wanda. 1991. „Leksykografia terminologiczna”. In Teoretyczne podstawy terminologii. Katedra Języków Specjalistycznych Uniwersytetu Warszawskiego. Warszawa. 